\title{
Relationship between Board Remuneration and Financial Performance in the Kenyan Financial Services Industry
}

\author{
Rita Ruparelia $^{1} \&$ Amos Njuguna ${ }^{1}$ \\ ${ }^{1}$ Chandaria School of Business, Nairobi, Kenya \\ Correspondence: Rita Ruparelia, Chandaria School of Business, P.O Box 14634-0800 Nairobi, Kenya. Tel. \\ 254-7-3362-2666.
}

Received: March 26, 2016

Accepted: April 14, 2016

Online Published: April 18, 2016

doi:10.5430/ijfr.v7n2p247

URL: http://dx.doi.org/10.5430/ijfr.v7n2p247

\begin{abstract}
Board remuneration has attracted considerable interest amongst financial analysts and scholars as it is seen to be a deterrent to financial scandals that have rocked corporates in the $21^{\text {st }}$ Century. This study sought to determine the effect of board remuneration on financial performance, focussing on commercial banks, insurance companies and investment companies listed at the Nairobi Securities Exchange from 2003 to 2013. Grounding the study on the agency theory, the study postulated that board remuneration will positively influence financial performance. Secondary data was obtained from audited financial statements for the 11 years ending 2013. Board remuneration was measured by director annual fees, while financial performance was measured using the proxies; return on assets (ROA), return on equity (ROE), dividend yield (DY), and earnings per share (EPS). A linear regression model was used on pooled cross-sectional time-series data to draw the inferences of the study. The results disclose significant variations in the level of board remuneration across the companies and a significant relationship between board remuneration and DY, but not ROA, ROE, and EPS. When disaggregated to financial market segments, the results confirmed a statistically significant relationship between board remuneration and with dividend yield in the banking sector. The same was not reported for ROA, ROE, and EPS. In the insurance segment, there was a statistical significance between board remuneration and ROA only, while in the investment sector, there was no significant relationship between board remuneration and financial performance measures.
\end{abstract}

Keywords: board remuneration, financial performance, return on assets, return on equity, dividend yield, earnings per share

\section{Introduction}

Financial performance of an entity is important to stakeholders in general, and to shareholders in particular as it increases the business value, offers the basis for the distribution of dividends, and may be used to attract potential investors (Muller, 2014). The identification and analysis of factors that influence financial performance is crucial, both in theory and practice.

There is an adage to the effect that "you get the board you pay for" (Lipman \& Hall, 2008) implying that the quality of the board and consequent value that the board creates for the corporate is a function of its compensation in the form of the basic pay, pension, in kind benefits as well as performance-related compensation such as bonus and share options (Gong, 2007; Carola \& Saks, 2010; Miyienda, Oirere \& Miyogo, 2012). It is therefore not surprising that board compensation is the most debated topics in corporate governance (Barontini \& Bozzi, 2009), has increased significantly in the past two decades and has received considerable attention to the media, regulators and advocates of voluntary adoption of governance codes (Sheikh \& Wang, 2012; Adams, 2012). The authors suggest that to attract and retain experienced and well connected persons to the board, the firm must provide an attractive package to its directors. This has however not always yielded fruit as directors have in the past awarded themselves large salaries despite poor profits pointing to greed in executive management or weak governance by shareholders (Miyienda et al, 2012). The need for controls to reduce the risk is therefore imminent and has led to development of governance guidelines starting with the Greenbury Report of 1995 which focused on establishing a balance between salary and performance as a way of restoring shareholder confidence.

The 2008-09 financial crisis raised serious concerns about the role of corporate governance mechanisms in determining remuneration and incentive systems (Fahlenbrach \& Stulz, 2011; Chesney, Stromberg \& Wagner, 2012) 
with empirical analyses showing a positive link between remuneration of both the executive and the board on risk taking behaviors. In essence, critics have claimed that high levels of compensation may compel directors to turn a blind eye to irregularities, as was established after the collapse of WorldCom (Lublin \& Bulkeley, 2006), the Enron case as we; as the Lehman Brothers Holdings where independent directors were accused of selling large quantities of shares prior to the collapse of the company, to boost returns on stock options (Aebi, Sabato \& Schmid, 2011).

The importance of board compensation has led to various attempts to have it regulated. For instance, the Greenbury report (1995) in the UK sought to regulate the compensation. Similarly in the Unites States, the Sarbanes-Oxley Act of 2002 was introduced to deal with corporate compensation in response to major scandals like Enron and WorldCom (Pokrashenko, 2012). The Sarbanes Oxley Act also tried to restrict the corporate board structure (Chen, 2012). It is often believed that it is the role of the executive and non-executive directors of a company to create value and profits for the company. There are studies that have showed a positive relationship between board remuneration and company performance, which is stronger for book values than for stock market measures. Industry performance also explains the remuneration and provides useful information to evaluate board behaviour (Scholtz \& Smit, 2012).

In Kenya, the desire to institutionalize the principles of corporate governance led to the promulgation of the "Guidelines on Principles of Corporate Governance for Public Listed Companies" in 2002 by the Capital Market Authority (CMA) (Gakeri, 2013). The Kenyan codes borrowed from the Hong Kong, Singapore, and Malaysian Codes of Governance, which are themselves replications of the United Kingdom's Combined Code (Mulili \& Wong, 2010). The collapse of Nyaga Stock Brokers and allegations that the firm was illegally making transactions on behalf of their clients despite the fact that they had not been given instructions led to the loss of millions. Investigations established that the information submitted to the Capital Markets Authority (CMA) was manipulated to give the impression that the company was meeting the requirements of the CMA and hide the fact that the company's financial base could not support its operations (Riungu, 2014). The near collapse of Uchumi Supermarket is another case in point; after years of rapid expansion, signs of trouble emerged with the closure of 10 branches in 2006. The supermarket went on and issued a rights issue of 1.2 billion which saw a majority of its shareholders shed off their shareholding from $52 \%$ to less than $20 \%$ necessitating the Board of Directors to declare the firm insolvent. The company was placed under receivership, restructured, and reopened on a Kshs. 675 million (USD 6.75 million) from the government (Turana, 2010).

There has been an exponential increase in all the pay levels of directors and CEOs irrespective of their performances (Sheikh and Wang, 2012). The first ever attempt to control director's compensation came with the introduction of Greenbury report (1995) in the UK. Similarly in the Unites States, the Sarbanes-Oxley Act of 2002 was introduced to deal with corporate compensation in response to major scandals like Enron and WorldCom, but it has been linked to excessive CEO compensation (Pokrashenko, 2012). In relation to the second issue discussed in this study (Board of directors), the Sarbanes Oxley Act also tried to restrict the corporate board structure (Chen, 2012). It is often believed that it is the role of the executive and non-executive directors of a company to create value and profits for the company. There are studies that have showed a positive relationship between board remuneration and company performance, which is stronger for book values than for stock market measures. Industry performance also explains the remuneration and provides useful information to evaluate board behaviour (Scholtz \& Smit, 2012).

Doucouliagos, Askary, and Haman (2006) explored the relationship between director's pay and performance among Australian banks. The data covered the 1992-2005 period. The findings showed that there was no significant contemporaneous relationship between director's remuneration and firm performance. However, when the data was lagged for two years, there was a distant relationship between board remuneration and earnings per share (EPS) and ROE. In addition to performance-based pay for directors, the study also established that managerial policies, bank size, and director's stock ownership also affect the level of pay. While there was no evidence of the effect of board remuneration on financial performance, the study established a positive and significant association between CEO remuneration and bank performance.

Gong and Li (2007) explored the relationship between independent director's equity-based compensation and board effectiveness, in terms of financial reporting and earnings management. The paper utilized a sample of S\&P 500 firms. S\&P's ExecuComp database was used in the estimation of the directors' option incentives, while the Investor Responsibility Research Center (IRRC) was used to measure stock incentives. A regression model was used to estimate the relationship. The findings showed that stock option incentives are negatively associated with meeting/beating earnings benchmarks. Evidence also showed that the independent directors were involved in the manipulation of option-based incentives and manipulated earnings in trading shares and granting stock options. 
Another study which related both director's and CEO pay and firm performance was Zhu, Tin, and Ma (2009). The study established that independent directors of a board can impact CEO pay performance more effectively if a compensation committee provides information and assist them in designing relevant executive pay schemes. The researchers established that there is a significant relationship between CEO pay and performance when a larger proportion of independent directors serve on the board. This association is more evident in those firms which have a compensation committee.

In another study, Barontini and Bozzi (2009) investigated the effect of corporate ownership and board remuneration on the performance of Italian listed firms at the Milan Stock Exchange. The data covered the period 1995-2002. The study established that there was a significant relationship between board remuneration and corporate ownership characteristics such as ownership concentration, type of controlling shareholder, and shareholders' agreements. Further, board remuneration was associated with firm performance. However, excessive compensation was not significantly related to future performance of the firm. In family owned and run firms, high levels of compensation was linked to small board size, high representation of family members in the board of directors, and lower future performance. The study concluded that control mechanisms and transparency was important in providing governance and oversight over board compensation to ensure future performance.

Miyienda et al., (2012) investigated the relationship between director remuneration and performance among firms listed at the NSE, for the period 2006-2010. The study used a sample of 57 listed firms. Regression analysis was used to establish the association between board remuneration and three financial performance measures: return on equity (ROE), earnings after taxes, and Tobin's Q. The findings demonstrate a positive link between board remuneration and financial performance; however, there was a weak relationship with ROE and Tobin's Q, but a moderately strong relationship with earnings after taxes. The researchers suggest that this difference implies that director's remuneration among listed companies at the NSE is linked to raw financial performance measures such as earnings after taxes, as opposed to financial ratios that determine the efficiency of utilizing shareholder funds. This may be an indication of an agency problem, where directors benefit from raw earnings but do not commit to the long term improvement in the utilization of shareholder funds and improving the market performance of the firm.

Yatim (2013) investigated directors' remuneration and corporate governance in Malaysia. The study used a sample of 428 companies for the 2008 financial year. The findings demonstrate that director's remuneration is positively and significantly associated to financial performance and growth opportunities. On the contrary, the study also showed that director's remuneration is negatively and significantly related to board independence. Of note was also the importance of remuneration committee to set compensation packages. However, while the number of companies included in the sample was significantly high, the study only utilized financial performance for one year. Further, there was no differentiation with regard to the components of remuneration packages such as salaries, bonuses, and other benefits.

Müller (2014) sought to determine whether corporate board compensation characteristics influence the financial performance of listed companies on the London Stock Exchange, FTSE100. Data was obtained for 2010-2011 financial years. The study used econometric regression models to establish the effect of five corporate governance characteristics related to board remuneration on the financial performance measured as ROA and ROE. Ordinary Least Squares (OLS) was used to establish the level of significance. The findings show a positive and significant relationship between board remuneration and the financial performance of companies. One major limitation of the study was that data was drawn from only one financial year.

Traditionally, the compensation of director's and CEO has associated with performance. But there has been an exponential increase in all the pay levels of directors and CEOs irrespective of their performances (Sheikh \& Wang, 2012). However, findings reported by various studies show conflicting results. There are several possible explanations for conflicting results. The first is that there are institutional differences across countries in which these studies were carried out. For instance, there are differences in studies conducted in European and Western context (Gupter, Kennedy \& Weaver, 2006; Stanwick, P \& Stanwick S, 2010) and other studies are conducted in Asian countries (Ponnu, 2008; Haat, Abdul \& Mahenthiran, 2008; Ghazali, 2010) and China (Sami, Wang \& Zhou, 2011) as well as in Middle Eastern countries such as Egypt (Kholeif, 2008) and Iran (Mashayekhi \& Bazaz, 2008) and others in African countries. The intra-countries institutional differences partially explains the governance-performance relationship inconclusive results and, at the same time, raises concern about whether the principles of corporate governance which originated from developed countries are applicable in other countries. Despite having corporate governance issues in Kenya, studies on the link between board remuneration and firm 
performance are lacking. This paper examines relationship between director remuneration and financial performance among companies listed at the Nairobi Securities Exchange.

The rest of the paper is organized as follows; section two provides the theoretical basis of the paper, section three details the research methodology, section four provides the results while section five, six and seven provide the discussion of results conclusions and recommendations respectively.

\section{Theoretical Review}

From the perspective of agency theory, the link between director's pay and firm performance provides an important incentive through which the board of directors can be used to tackle the agency problem. However, increasing levels of director's pay over the past two decades has elevated attention and concern among shareholders making it an agency problem as opposed to being a solution to the agency problem (Yatim, 2010).

Originating from the seminal papers of Alchian and Demsetz (1972) and Jensen and Meckling (1976) the theory is based on the contractual view of the firm, and focuses on the relationship between the principals such as shareholders and the agents such as the executives and managers of the company. This relationship is a contractual arrangement where the principal engages the agent to perform some service. It is the expectation of the principal that the agent will act in their best interests, however due to opportunistic behaviour, the agent may not necessarily act in the best interest of the principal (Padilla, 2002). The executive management are agents that have been employed by shareholders (principals) to maximize firm returns. Since the agents do not own the resources, they may commit moral hazards such as shirking their duties to enjoy leisure or hide their inefficiency to avoid the loss of rewards, or in other words, engage in actions that enhance their own personal wealth at the expense of the principals. The agency problem arises when "(a) the desires or goals of the principal and agent conflict and (b) it is difficult or expensive for the principal to verify what the agent is actually doing" (Eisenhardt, 1989).

To minimize the potential for such agency problems, the scholars noted that two important steps must be met: first, the principal-agent risk-bearing mechanism must be designed efficiently and second, the design must be monitored through the nexus of organizations and contracts (Mukaila, Sanda \& Garba, 2005). The first step, considered as the formal agency literature, examines how much of risks should each party assume in return for their respective gains. The principal must transfer some rights to the agent who, in turn, must accept to carry out the duties enshrined in the rights. The second step, clarifies how firms use contractual monitoring and bonding to bear upon the structure designed in the first step and derive potential solutions to the agency problems. The inevitable loss of firm value that arises with the agency problems along with the costs of contractual monitoring and bonding are defined as agency costs (Jensen, 1993).

There are various ways through which firms can structure their corporate governance in order to control the agency problem that has been created by the separation of ownership and control. One of the mechanisms was put forward by Fama (1980), who stated that the agency problem can be controlled efficiently by a large firm through internal devices that have been established to respond to competition from other firms. Therefore, "individual managers within the firm are controlled by the market's discipline and opportunities for their services both within and outside the firm" (Fama, 1980). Since firms typically segregate decision management from the decision control rights both at the top (board and managers) and at lower levels (managers and workers), decision management ensures that situations where the agent who has no ownership of the firm's resources and may enhance self-interest by decisions that are suboptimal to the principal are avoided. Therefore, the owners of the corporation appoint the board of directors as a corporate governance solution to control the agency problem which may arise from the decisions of the management. Therefore, the board holds decision control authority, while the managers hold decision management rights.

Another way in which corporate governance acts as a solution to the agency problem is through the constitution and compensation of the board. The appointment of outside directors ensures that there is objectivity in the making of internal director's decisions. Thus, if a director performs the duties and responsibilities efficiently, the shareholders may offer share-based incentives such as stock grants or options. It is expected that such incentive contracts help in aligning the interests of the management and shareholders hence dealing with agency problems (Cullen, Kirwan \& Brennan, 2012). The internal and external governance mechanisms such as effective board structure, compensation contracts, active monitoring of executives through concentrated ownership and corporate control, play an important role in aligning the interests of the agents and principals. As such, the agency theory provides a broad analytical framework that can be utilized in examining how corporate governance systems can successfully curb opportunistic managerial behaviour and in the process secure a fair return on investment for the suppliers of finance. 


\section{Methodology}

A cross sectional survey design was used in the study. Panel-data for 20 listed financial services companies for the period 2003-2013. Audited annual financial statements were obtained from NSE and CMA for the board remuneration and financial performance.

Pooled cross-sectional time-series data analysis was done using the mixed procedure to estimate the relationship board remuneration and financial performance. The linear regression model applied took the form of:

$$
Y=\beta 0+\beta 1 B R+\varepsilon
$$

Where:

$\mathrm{Y}=$ Financial Performance measured as Return on Assets (ROA), Return on Equity (ROE), Dividend Yield (DY), and Earnings Per Share (EPS)

$\mathrm{BR}=$ Board Remuneration (BR)

$\varepsilon=$ Error term

$\beta 1=$ slope of the regression equation

The coefficient of determination was used to determine the strength of the relationship whilst standardized coefficients were used to determine the comparative explanatory power, direction and significance of the explanatory variables in the regression model.

\section{Results}

\subsection{Descriptive Statistics}

The data discloses are significant variations between companies on the amount of annual remuneration made to the boards. Board remuneration ranged from 1.1 million to 102 million, with a mean of 11.142. ROA ranged from $-1.97 \%$ to $18.63 \%$; ROE from $-16.26 \%$ to $49.82 \%$; DY from 0 to $11.15 \%$; and EPS ranged from $-13.63 \%$ to $37.0 \%$. The descriptive statistics are shown in Table 1. Trend analysis shows a steady increase in board remuneration from Kshs 4.6 million in 2003 and the highest remuneration was Kshs 22.23 million in 2013. The means for the years were: 4.6M (2003), 5.56M (2004), 6.67M (2005), 7.43M (2006), 6.96M (2007), 7.3M (2008), 8.65M (2009), 9.49M (2010), 14.77M (2011), 17.6M (2012), and 22.23M (2013).

Table 1. Descriptive statistics for variables

\begin{tabular}{lrrrrr}
\hline & N & \multicolumn{1}{c}{ Minimum } & \multicolumn{1}{c}{ Maximum } & \multicolumn{1}{c}{ Mean } & \multicolumn{1}{c}{ Std. Deviation } \\
\hline BR & 110 & 1.1 & 102.0 & 10.142 & 15.1396 \\
ROA & 110 & -1.97 & 18.63 & 3.2565 & 2.78669 \\
ROE & 110 & -16.26 & 49.82 & 17.7545 & 10.65722 \\
DY & 100 & .00 & 11.15 & 3.1730 & 2.48986 \\
EPS & 100 & -13.63 & 37.00 & 5.5310 & 6.69586 \\
Valid N (listwise) & 100 & & & & \\
\hline
\end{tabular}

\subsection{Correlation Analysis}

A weak correlation was reported between board remuneration and ROA (2.1\%), ROE (17.9\%), DY (27.3\%) and EPS $(1.25 \%)$ in the financial services industry. The relationship between board remuneration and ROA $(r=-0.021)$ and EPS $(\mathrm{r}=-0.125)$ was negative. Further, the relationship between board remuneration and dividend yield was significant ( $\mathrm{p}=0.006 \propto 0.01$ level), while that of ROA ( $\mathrm{p}=0.830)$, ROE $(0.061)$ and EPS $(0.216)$ was insignificant both at the 0.01 and 0.05 level, as shown in Table 2 . 
Table 2. Bivariate correlations

\begin{tabular}{llrrrrr}
\hline & BR & ROA & ROE & DY & \multicolumn{1}{l}{ EPS } \\
\hline BR & Pearson Correlation & 1 & -.021 & .179 & $.273^{* *}$ & -.125 \\
& Sig. (2-tailed) & & .830 & .061 & .006 & .216 \\
$\mathrm{~N}$ & 110 & 110 & 110 & 100 & 100 \\
\hline **. Correlation is significant at the 0.01 level (2-tailed). & & & & & \\
*. Correlation is significant at the 0.05 level (2-tailed). & & & & & \\
\hline
\end{tabular}

\subsection{Regression Analysis}

Regression analysis show that board remuneration is a stronger predictor of dividend yield (7.4\%), than it is for ROA $(0.00 \%)$, ROE (3.2\%), and EPS (1.6\%). In the same way, only the model for DY was found to be a significant predictor of the dependent variable $(\mathrm{p}=0.006)$. The findings show a statistically significant relationship between board remuneration and with dividend yield $(\mathrm{p}=0.013)$, but no statistical significance with ROA $(\mathrm{p}=0.560)$, ROE $(\mathrm{p}=0.187)$, and EPS $(\mathrm{p}=0.200)$ in the banking sector. In the insurance sector, there a statistical significance between board remuneration and ROA $(p=0.013)$ and $\operatorname{ROE}(p=0.036)$, but not DY $(p=0.250)$ and EPS $(p=0.483)$. In the investment sector, there is no significant relationship between board remuneration and financial performance in the investment sector; ROA ( $p=0.767)$, ROE $(\mathrm{p}=0.837)$, DY $(\mathrm{p}=0.305)$, and EPS $(\mathrm{p}=0.938)$. Overall, the findings show that there is a significant relationship between board remuneration and dividend yield $(\mathrm{p}=0.006)$ in the financial services industry. However, the relationship between board remuneration and ROA $(p=0.830), \operatorname{ROE}(\mathrm{p}=0.061)$, and EPS $(\mathrm{p}=0.216)$ was not significant at the industry level. These results are reported in Table 3.

Table 3. Regression coefficients board remuneration and financial performance in the industry

\begin{tabular}{|c|c|c|c|c|c|c|}
\hline \multirow[t]{2}{*}{ Model } & & \multicolumn{2}{|c|}{ Unstandardized Coefficients } & \multirow{2}{*}{$\begin{array}{c}\text { Standardized } \\
\text { Coefficients }\end{array}$} & \multirow[t]{2}{*}{$\mathrm{T}$} & \multirow[t]{2}{*}{ Sig. } \\
\hline & & B & Std. Error & & & \\
\hline \multirow{2}{*}{ ROA } & (Constant) & 3.295 & .322 & & 10.244 & .000 \\
\hline & Board Remuneration & -.004 & .018 & -.021 & -.215 & .830 \\
\hline \multirow{2}{*}{ ROE } & (Constant) & 16.477 & 1.211 & & 13.611 & .000 \\
\hline & Board Remuneration & .126 & .067 & .179 & 1.890 & .061 \\
\hline \multirow{2}{*}{ DY } & (Constant) & 2.691 & .296 & & 9.096 & .000 \\
\hline & Board Remuneration & .054 & .019 & .273 & 2.804 & .006 \\
\hline \multirow{2}{*}{ EPS } & (Constant) & 6.124 & .820 & & 7.464 & .000 \\
\hline & Board Remuneration & -.066 & .053 & -.125 & -1.244 & .216 \\
\hline
\end{tabular}

\section{Discussion of the Results}

The study does not demonstrate a positive and significant relationship between board remuneration and all the measures of financial performance. Like in Miyienda et al (2012), which investigated the relationship between director remuneration and performance among firms listed at the NSE, for the period 2006-2010, the study shows no relationship between board remuneration and some financial performance ratios that determine the efficiency of utilizing shareholder funds and market performance. It is generally accepted that high compensation encourages directors to perform their roles more effectively. This study does not confirm a positive relationship. Nonetheless, there are other researchers that have reported inconclusive results as to the relationship between board compensation and financial performance. For instance, Duffhues \& Kabir (2008) did not report any significant relationship between board compensation and corporate performance, and Conyon \& Schwalbac (2000) found inconclusive evidence. The finding of the study show inconclusive evidence since board remuneration is only positively related to dividend yield, and not to ROA, ROE, and EPS. Yatim (2013) did a cross sectional analysis of 428 firms in Malaysia and found that directors' compensation was positively and significantly related to firm performance. 
ROA and ROE are indicators of the efficiency of the business to generate profitability, while earnings per share demonstrated how the company's shares are performing in the market. The findings show that board remuneration does not affect ROA, ROE, and EPS. On the other hand, dividend yield is a measure of shareholder returns. A dividend is a pro rata distribution to shareholders that is declared by the company's board of directors (King'wara, 2015). The positive and significant relationship shows that directors are effectively performing their role of maximizing shareholder wealth. In agency theory, dividend payments is one of the tools for controlling agency behaviour, even though it increases transaction costs associated with raising external funding (Manos, 2002). It can also be stated that, in corporate governance, dividends serve as a disciplining and monitoring mechanism used by the board to reduce the agency costs of equity. Finally, dividends are crucial in institutional frameworks where governance provisions are unfavourable for shareholders (Haye, 2014).

\section{Conclusions}

This study has generated evidence to the effect that;

- Board remuneration in the financial services industry in Kenya has increased significantly in the eleven years ending 2013.

- There is significant variation in board remuneration amongst the firms in the financial services industry in Kenya.

- The effect of board remuneration on the dividend yield in the overall industry is significant but when the data is disaggregated, the relationship does not hold for the insurance sector or the investment services sector of the financial services industry in Kenya.

- The effect of board remuneration on the earnings per share, return on equity and return on assets in the overall industry is significant but when the data is disaggregated, a the relationship is not observed in the banking or investment services sectors.

- Board remuneration a stronger predictor of the dividend yield than it is for return on assets, return on equity and earnings per share in the Kenyan financial service industry.

- Board remuneration does not influence either the dividend yield, return on equity, return on assets or earnings per share in the investment sector of the financial services industry in Kenya.

\section{Recommendations and Suggestions for Further Research}

The conclusions of the study imply that the analysis of board remuneration and corporate governance by extension should be studied bearing in mind the specific subsectors of the industries under consideration as opposed to the aggregate industries Measures for improvement should therefore be tailored to the specific sub-sectors.

The main limitation of the study is that it relied exclusively on secondary data to draw its inferences and consequent conclusions. We suggest that future researchers undertake a qualitative study to establish the factors that explain the reasons for the statistically significant relationship between the board remuneration and the dividend yield and also the reasons that account for the variations in the results between the industry sub sectors. Additionally, future research should focus on non-financial firms.

\section{References}

Adams, R.B. (2012). Governance and the financial crisis. International Review of Finance, 12(1), 7-38. http://dx.doi.org/10.1111/j.1468-2443.2011.01147.x

Aebi, V., Sabato, G., \& Schmid, M. (2010). Risk Management, Corporate Governance, and Bank Performance in the Financial Crisis. 10th GUBERNA European Corporate Governance conference in Brussels (2010) and the University of St. Gallen, January.

Alchian, A., \& Demsetz, H. (1972). Production, Information Costs, and Economic Organization. American Economic Review, I62, 777-795.

Barontini, R., \& Bozzi, S. (2009). Board compensation and ownership structure: empirical evidence for Italian listed companies. J Manag Gov. http://dx.doi.org/10.1007/s10997-009-9118-5

Carola, F., \& Saks, R.E. (2010). Executive Compensation: A New View from a Long-Term Perspective, 1936-2005. The Review of Financial Studies, 23(5), 2100-2138.

Chen, I. (2012). Corporate Governance and Capital Allocations of Diversified Firms. Journal of Banking and Finance, 36(2), 395-409. http://dx.doi.org/10.1016/j.jbankfin.2011.07.013 
Chesney, M., Stromberg, J., \& Wagner, A.F. (2012). Risk-taking incentives and losses in the financial crisis. Working paper, Swiss Finance Institute, Switzerland.

Cheung, Y., Connelly, J.T., Limpaphayom, P., \& Zhou, L. (2007). Do investors really value corporate governance? Evidence from the Hong Kong market. Journal of International Financial Management and Accounting, 18(2), 86-122. http://dx.doi.org/10.1111/j.1467-646X.2007.01009.x

Cullen, M., Kirwan, C., \& Brennan, N. (2012). Comparative Analysis of Corporate Governance Theory: The Agency-Stewardship Continuum. Paper presented at the 20th Annual Conference of the Irish Accounting \& Finance Association, Institute of Technology Tralee, 10-11 May.

Doucouliagos, H., Askary, S., \& Haman, J. (2006). Director's remuneration and performance in Australian Banking. Faculty of Business and Law, Deakin University.

Eisenhardt, K.M. (1989). Agency Theory: An Assessment and Review. International Journal of Management, 5 , 341-353.

Fahlenbrach, R., \& Stulz, R. M. (2011). Bank CEO Incentives and the credit risk. Journal of Financial Economics, 99(1), 11-26. http://dx.doi.org/10.1016/j.jfineco.2010.08.010

Fama, E.F. (1980). Agency Problems and the Theory of the Firm. The Journal of Political Economy, 88(2), 288-307. http://dx.doi.org/10.1086/260866

Gakeri, J.K. (2013). Enhancing Kenya's Securities Markets through Corporate Governance: Challenges and Opportunities. International Journal of Humanities and Social Science, 3(6), 96-117.

Ghazali, N.A.M. (2010). Ownership structure, corporate governance and corporate performance in Malaysia. International Journal of Commerce and Management, 20(2), 109-119. http://dx.doi.org/10.1108/10569211011057245

Gong, G., \& Li, H. (2007). Outside Directors' Equity-based Compensation and Earnings Management. University of Iowa.

Greenbury, R. (1995). Director's Remuneration: Report of a Study Group chaired by Sir Richard Greenbury. European Corporate Governance Institute.

Gupta, P., Kennedy, D., \& Weaver, S. (2009). Corporate Governance and Firm Value: Evidence from Canadian Capital Markets. Corporate Ownership and Control Journal, 6(3), 293-307.

Haat, M.H., Abdul, R.R., \& Mahenthiran, S. (2008). Corporate governance, transparency and performance of Malaysian companies. Managerial Auditing Journal, 23(8), 744-778. http://dx.doi.org/10.1108/02686900810899518

Haniffa, R. M., \& Cooke, T. E. (2002). Culture, corporate governance and disclosure in Malaysian corporations. ABACUS, 38(3), 317-349. http://dx.doi.org/10.1111/1467-6281.00112

Jensen, M.C. (1993). The Modern Industrial Revolution, Exit and the Failure of Internal Control Systems. The Journal of Finance, 48(3), 831-880. http://dx.doi.org/10.1111/j.1540-6261.1993.tb04022.x

Jensen, M.C. (1976). Meckling WH. Theory of the Firm: Managerial Behavior, Agency Costs and Ownership Structure. Journal of Financial Economics, 3, 305-360. http://dx.doi.org/10.1016/0304-405X(76)90026-X

Kholeif, A. (2008). CEO duality and accounting-based performance in Egyptian listed companies: a re-examination of agency theory predication. Research in Accounting in Emerging Economies, 8, 65-98. http://dx.doi.org/10.1016/S1479-3563(08)08003-1

Lipman, F., \& Hall, S. (2008). Executive compensation best practices. Hoboken, N.J.: John Wiley \& Sons.

Lublin, J.S., \& Bulkeley. (2006). WM. IBM ends director stock options, spotlighting popular perk's decline. The Wall Street Journal.

Mashayekhi, B.A., \& Bazaz, M.S. (2008). Corporate governance and firm performance in Iran. Journal of Contemporary Accounting \& Economics, 4(2), 156-172. http://dx.doi.org/10.1016/S1815-5669(10)70033-3

Miyienda, M., Oirere, C.O., \& Miyogo, J. (2012). The relationship between director remuneration and performance of firms listed in the Nairobi Securities Exchange. The International Journal of Social Sciences, 15(1), 1-17. 
Mukaila, A.S., Sanda, A.U., \& Garba, T. (2005). Corporate Governance Mechanisms and Firm Financial Performance in Nigeria. Final Report Presented to the Biannual Research Workshop of the AERC, Nairobi, Kenya.

Mulili, M.B., \& Wong, P. (2010). Corporate Governance in Developing Countries. The Case for Kenya. International Journal of Business Administration, 2(1), 1-15.

Müller, V. (2014). Do corporate board compensation characteristics influence the financial performance of listed companies? Procedia-Social and Behavioural Sciences, $109, \quad 983-988$. http://dx.doi.org/10.1016/j.sbspro.2013.12.575

Padilla A. (2002). Can Agency Costs Justify the Regulation of Insider Trading?. The Quarterly Journal of Austrian Economics, 5, 3-38. http://dx.doi.org/10.1007/s12113-002-1015-6

Pokrashenko, P. (2012). Cost efficiency of Russian banks: the impact of board of directors and executive group. Economics Education and Research Consortium. Working Paper. 12/02E. 2-31.

Ponnu, C. (2008). Corporate governance structures and the performance of Malaysian public listed companies. International Review of Business Research Papers, 4(2), 217-230.

Sami, H., Wang, J., \& Zhou, H. (2011). Corporate governance and operating performance of Chinese listed firms. Journal of International Accounting, Auditing and Taxation, 20, 106-114. http://dx.doi.org/10.1016/j.intaccaudtax.2011.06.005

Scholtz, H.E., \& Smit, A. (2012). Executive remuneration and company performance for South African companies listed on the Alternative Exchange (AltX). SA Business Review, 16(1), 22-38.

Sheikh, N.A., \& Wang, Z. (2012). Effects of corporate governance on capital structure: empirical evidence from Pakistan. Corporate Governance, 12(5), 629-641. http://dx.doi.org/10.1108/14720701211275569

Stanwick, P.A., \& Stanwick, S.D. (2010). The relationship between governance and financial performance: an empirical study of Canadian firms. The Business Review, 16(2), 35-41.

Turana, J. (2010). Tackle Boardroom Queries on Corporate Governance, BUSINESS DAILY, Apr. 12, 2010.

Yatim, P. (2010). Director's Remuneration and Corporate Governance in Malaysia. Universiti Kebangsaan Malaysia.

Zhu, Y, Tian, G.G., \& Ma, S. (2009). Executive compensation, board characteristics and firm performance in China: the impact of compensation committee. 22nd Australasian Finance and Banking Conference (2009: 1-48). Sydney, Australia: Social Science Electronic Publishing, Inc. http://dx.doi.org/10.2139/ssrn.1460590 